Tropical Journal of Pharmaceutical Research February 2021; 20 (2): 301-308

ISSN: $1596-5996$ (print); 1596-9827 (electronic)

(C) Pharmacotherapy Group, Faculty of Pharmacy, University of Benin, Benin City, 300001 Nigeria.

\title{
Protective effect of purple sweet potato leaf (Ipomoea batatas Linn Convolvulaceae) against alcohol-induced liver damage in mice
}

\author{
Hyun Kang and Sung-Gyu Lee* \\ Department of Medical Laboratory Science, College of Health Science, Dankook University, 119, Dandae-ro, Dongnam-gu, \\ Cheonan-si, Chungnam 31116, Korea
}

*For correspondence: Email: sung-gyu@gmail.com; Tel: +82-41-529-6053; Fax: +82-41-550-8037

Sent for review: 11 March 2020

Revised accepted: 20 January 2021

\begin{abstract}
Purpose: To investigate the hepatoprotective effect of Ipomoea batatas extract against alcohol-induced liver damage in mice.

Methods: Male C57BL/6 mice were randomly divided into 4 experimental groups $(n=10)$. Normal Group: The animals received distilled water $5 \mathrm{ml} / \mathrm{kg}$ for 7 days; Alcohol Group: The animals received alcohol $5 \mathrm{ml} / \mathrm{kg}$ of $40 \% \mathrm{w} / \mathrm{v}$ alcohol for 7 days; Alcohol + Purple sweet potato leaf extract (PSPE) Group: PSPE $400 \mathrm{mg} / \mathrm{kg}$ was for 7 days. The animals received alcohol $5 \mathrm{ml} / \mathrm{kg}$ of $40 \% \mathrm{w} / \mathrm{v}$ alcohol for 7 days; Alcohol + Hovenia dulcis Thunb extract (HDE) Group: HDE $400 \mathrm{mg} / \mathrm{kg}$ was for 7 days. To confirmed to the liver protection effect of PSPE, it was calculated, and the levels of alanine aminotransferase (ALT), aspartate aminotransferase (AST), triglyceride (TG), and total cholesterol (TC) in serum were detected. To evaluate changes of histological in alcohol-fed mice, liver tissue was determined by H\&E staining.

Results: Blood alcohol concentration in purple sweet potato leaf extract (PSPE) $200 \mathrm{mg} / \mathrm{kg}$ and Hovenia dulcis (H. dulcis) extract (HDE) $200 \mathrm{mg} / \mathrm{kg}$ treated group significantly decreased compared to alcohol with water treated group $(p<0.05)$. Serum ALT (alanine aminotransferase) and AST (aspartate aminotransferase) were markedly reduced. Liver sections in mice stained with H\&E (hematoxylin and eosin) stain to displayed the physiological changes in the liver tissue. Furthermore, the results showed that inflammatory cells increased in the alcohol group compared to the normal group, but spontaneously decreased in the PSPE or HDE-treated group.

Conclusion: These results demonstrate that Ipomoea batatas may be therapeutically effective in protecting the liver from alcohol-induced hepatotoxicity and fatty liver.
\end{abstract}

Keywords: Ipomoea batatas, alcohol, Hepatoprotective, AST (aspartate aminotransferase) ALT (alanine aminotransferase)

This is an Open Access article that uses a fund-ing model which does not charge readers or their institutions for access and distributed under the terms of the Creative Commons Attribution License (http://creativecommons.org/licenses/by/4.0) and the Budapest Open Access Initiative (http://www.budapestopenaccessinitiative.org/read), which permit unrestricted use, distribution, and reproduction in any medium, provided the original work is properly credited.

Tropical Journal of Pharmaceutical Research is indexed by Science Citation Index (SciSearch), Scopus, International Pharmaceutical Abstract, Chemical Abstracts, Embase, Index Copernicus, EBSCO, African Index Medicus, JournalSeek, Journal Citation Reports/Science Edition, Directory of Open Access Journals (DOAJ), African Journal Online, Bioline International, Open-J-Gate and Pharmacy Abstracts

\section{INTRODUCTION}

Alcoholic liver disease (ALD) is a leading cause of liver disease and associated with significant disease and mortality worldwide, including Korea
[1]. Alcohol consumption is also a major cause of liver disease because it could cause serious liver injuries and lead to liver fibrosis and cirrhosis [2]. Despite the insightful economic and influence impact of ALD, the underlying mechanisms of 
alcohol-induced liverdamage are ambiguous and targeted treatments are inaccessible. Therefore, there is a need to develop novel, safe and pathophysiological treatments for liver damage caused by alcohol.

Alcohol is mainly metabolized in the liver through three enzymatic paths: alcohol dehydrogenase $(\mathrm{ADH})$, acetaldehyde dehydrogenase (ALDH) and cytochrome p450 2E1 (CYP2E1). Excessive alcohol consumption leads to an increase in highly toxic acetaldehyde, which can damage membrane lipids and alter enzyme activity [3]. Acetaldehyde, the first metabolite of ethanol, is formed by alcohol oxidation through the action of $\mathrm{ADH}$. Since the liver serves as a major site for ethanol oxidation, there is ample evidence that acetaldehyde acts as a major cause of liver damage after chronic alcohol consumption [4].

Natural plant products are attracting a lot of attention as potential therapeutics in the prevention and treatment of ALD due to their low toxic side effects [5]. Purple sweet potato scientifically known as Ipomoea batatas Linn. from the family Convolvulaceae is a herbaceous perennial vine with white and purple flowers, large nutritious storage roots and heart-shaped, lobed leaves [6]. I. batatas mainly known as sweet potato has played an essential role as an energy source in human diet. The plant has significant medicinal importance and many parts of the plant are used in traditional medicine [7]. From the leaf of sweet potato, the caffeoylquinic acid derivatives such as 3-mono-O-caffeoylquinic acid, 3,4-di-O-caffeoylquinic acid, 3,5-di-Ocaffeoylquinic acid, 4,5-di-O-caffeoylquinic acid, 3,4,5-tri-O-caffeoylquinic acid, and Caffeic acid have been isolated [8]. These compounds were known to prevent proliferation of human cancer cells cause to colon cancer, stomach cancer, and promyelocytic leukemia cell [9].

However, few studies have been conducted on the hepatoprotective effect of purple sweet potato leaf. The present study was performed to investigate the possible effect of purple sweet potato leaf on alcohol induced-liver damage in mice.

\section{EXPERIMENTAL}

\section{Preparation of PSPE and HDE extracts}

In this study, purple sweet - potato leaf was collected at the end August to about the middle of September at Goesan-gun (Chungcheongbukdo, Korea). The raw materials were dried, ground to a fine powder ( 20 mesh) using a milling machine, and then extracted with $70 \%$ ethanol three times by stirring for $24 \mathrm{~h}$ at RT. After filtration the solvent was removed using a rotary vacuum evaporator, and the freeze-dried extract stored deep freezer $\left(-80^{\circ} \mathrm{C}\right)$ until used for further analysis. Hovenia dulcis Thunb extract (HD) were obtained from Natural F\&P Co. (Chungcheongbuk-do, Korea).

\section{Blood alcohol analysis}

Twenty male Sprague Dawley rats (age 6 weeks old) were obtained from DBL Inc. (Eumseonggun, Korea). All the experimental animals were divided in a group ( $n=5)$ and fed water and feed, under $12 \mathrm{~h}$ light and dark conditions. After a week, each of 5 animals were divided into alcohol group, alcohol + PSPE $100 \mathrm{mg} / \mathrm{kg}, 200$ $\mathrm{mg} / \mathrm{kg}, 300 \mathrm{mg} / \mathrm{kg}$ group, and alcohol + HDE 200 $\mathrm{mg} / \mathrm{kg}$ group. Rats were fasted for $18 \mathrm{~h}$ before the experiment, and water was supplied without restriction. The PSPE and HDE groups were orally administered PSPE and HDE $30 \mathrm{~min}$ before alcohol administration, and the alcohol group was orally administered distilled water (DW) instead of the sample. For alcohol administration, $30 \%$ alcohol was orally administered once at a level of $3 \mathrm{~mL} / \mathrm{kg}$. To measure the alcohol concentration, blood was collected through the tail vein at $0 \mathrm{~min}, 30 \mathrm{~min}$, and $2 \mathrm{~h}$ after alcohol administration. The collected blood was centrifuged at $4^{\circ} \mathrm{C}, 3,000$ rpm for $15 \mathrm{~min}$ to obtain serum, and immediately placed in a $-80^{\circ} \mathrm{C}$ deep freezer. In order to measure blood alcohol concentration, it was measured using an ethanol assay kit (BioVision Inc, Milpitas, CA, USA).

\section{Animals and experimental design}

Five-week-old male C57BL/6 mice were obtained from Daehan Bio Link Co. (Eumseong, Korea), and were maintained in an animal house at $22 \pm$ $2^{\circ} \mathrm{C}$ with a $12 \mathrm{~h}$ light/dark cycle. After a 1-week adaption period, the mice were divided in to 4 experimental groups $(n=10)$. The experimental group were divided as follows: Normal Group: The animals received DW $5 \mathrm{ml} / \mathrm{kg}$ for 7 days; Alcohol Group: The animals received alcohol 5 $\mathrm{ml} / \mathrm{kg}$ of $40 \% \mathrm{w} / \mathrm{v}$ alcohol for 7 days; Alcohol + Purple sweet potato leaf extract (PSPE) Group: PSPE $400 \mathrm{mg} / \mathrm{kg}$ was for 7 days; Alcohol + Hovenia dulcis Thunb extract (HD) Group: HDE $400 \mathrm{mg} / \mathrm{kg}$. PSPE and HD were administered 30 min before alcohol administration.

\section{Assessment of body weight change and feed and water intake}

Diets of the mice were fed a pellet diet (Rodent diet 2918C; Harlan Teklad, Indianapolis, IN, 
USA) with the water. During the 7 days experimental period, all groups measured body weight, diet and water intake before drug administration every day.

Analysis of AST, ALT, TC, and TG profiles in serum

At the end of treatment ( 7 days for alcohol treatment), the mice were sacrificed and the blood collected. The serum was obtained by centrifugation $\left(3,000 \mathrm{rpm}\right.$ for $15 \mathrm{~min}$ at $4{ }^{\circ} \mathrm{C}$ ) using a serum separator tube at $-70{ }^{\circ} \mathrm{C}$ to estimate serum aspartate aminotransferase (AST), alanine aminotransferase (ALT), triglyceride (TG), and total cholesterol (TC). The concentration of serum ALT, AST, TC, and TG were measured using a Konelab20XT automatic blood analyzer.

\section{Histopathological analysis}

Liver tissue was cut into small pieces at the time of sacrifice for histopathological analysis. The tissue blocks were then fixed in a $10 \%$ formaldehyde solution neutralized to $\mathrm{pH} 7.4$ for $24 \mathrm{~h}$, embedded into a paraffin block, successively cut into $4 \mu \mathrm{m}$-thick slices, placed on normal glass, deparaffinized in xylene twice for 5 $\mathrm{min}$, twice for $5 \mathrm{~min}$, and rehydrated with a series of graded alcohol. Each tissue slide was stained with Mayer's hematoxylin and eosin (H\&E) and observed under a microscope at magnification of 200.

\section{Determination of ADH activity}

Liver samples were grinded in cold PBS for homogenization and centrifuged at $3000 \mathrm{rpm}$ for $10 \mathrm{~min}$ to get supernatant. The levels of $\mathrm{ADH}$ were detected by ADH activity assay kit (BioVision Inc, Milpitas, CA, USA) based on the manufacturer's instructions. All results were standardized to total protein measured handling BCA protein assay Kit (ThermoFisher, MA, USA) based on the manufacturer's instructions.

\section{Chlorogenic acid contents analysis}

The method of analyzing the chlorogenic acid of PSPE was carried out by applying the method of European Pharmacopoeia 6.6. For pretreatment of the sample, $50 \mathrm{ml}$ of methanol was added to $0.5 \mathrm{~g}$ of PSPE and extracted with a reflux extractor at $70^{\circ} \mathrm{C}$ for $1 \mathrm{~h}$, and the supernatant obtained through centrifugation was placed in a $200 \mathrm{ml}$ quantitative flask and then filled up with distilled water (DW). As a standard solvent, 5.0 $\mathrm{mg}$ of chlorogenic acid was dissolved in $50 \mathrm{ml}$ methanol, and $5 \mathrm{ml}$ of this solution was placed in a $20 \mathrm{ml}$ quantitative flask, $5 \mathrm{ml}$ of methanol was added, and then filled up with DW. The HPLC analysis method was performed as shown in Table 1.

Table 1. HPLC analysis condition of chlorogenic acid

\begin{tabular}{|c|c|c|c|}
\hline Item & \multicolumn{3}{|c|}{ Condition } \\
\hline Column & \multicolumn{3}{|c|}{$\begin{array}{l}\text { - Size: I }=0.250 \mathrm{~m}, \varphi=4.6 \mathrm{~mm} \\
\text { - Stationary phase: octadecylsilyl silica gel for } \\
\text { chromatography } \mathrm{R}(5 \mu \mathrm{m})\end{array}$} \\
\hline $\begin{array}{l}\text { Oven } \\
\text { temperature }\end{array}$ & \multicolumn{3}{|l|}{$40^{\circ} \mathrm{C}$} \\
\hline \multirow{6}{*}{ Mobile phase } & \multicolumn{3}{|c|}{$\begin{array}{l}\text { - mobile phase A: phosphoric acid, water }(0.5 \text { : } \\
99.5, \mathrm{v} / \mathrm{v}) \\
\text { - mobile phase B: phosphoric acid, acetonitrile } \\
(0.5: 99.5 \mathrm{v} / \mathrm{v})\end{array}$} \\
\hline & $\begin{array}{l}\text { Time } \\
(\mathrm{min}) \\
\end{array}$ & $\begin{array}{c}\text { Mobile phase } A \\
\text { (percent } \mathrm{v} / \mathrm{v})\end{array}$ & $\begin{array}{c}\text { Mobile phase B } \\
\text { (percent v/v) }\end{array}$ \\
\hline & $0-1$ & 92 & 8 \\
\hline & $1-20$ & $92 \rightarrow 75$ & $8 \rightarrow 25$ \\
\hline & $20-33$ & 75 & 25 \\
\hline & 33-35 & $75 \rightarrow 0$ & $25 \rightarrow 100$ \\
\hline Flow rate & \multicolumn{3}{|l|}{$1.2 \mathrm{ml} / \mathrm{min}$} \\
\hline Detection & \multicolumn{3}{|c|}{ spectrophotometer at $330 \mathrm{~nm}$} \\
\hline $\begin{array}{l}\text { Injection } \\
\text { volume }\end{array}$ & \multicolumn{3}{|l|}{$25 \mu \mathrm{l}$} \\
\hline
\end{tabular}

\section{Statistical analysis}

All data are presented as mean \pm SEM. Statistical significance ( $p<0.05$ for all analyses) was assessed by ANOVA with Instat 3.05 (GraphPad, San Diego, CA), followed by Student-Newman-Keuls analysis

\section{RESULTS}

\section{Alcohol in blood concentration}

Alcohol concentration after oral administration of alcohol gotten a peak level of $11.06 \mathrm{nmole} / \mathrm{mM}$ at 30 min and declined gradually. The alcohol group only showed higher alcohol concentration at 30 min when compared to sample treated group. At 120 min, however, alcohol concentration in purple sweet potato leaf extract (PSPE) 300 $\mathrm{mg} / \mathrm{kg}$ and Hovenia dulcis ( $H$. dulcis) extract (HDE) $200 \mathrm{mg} / \mathrm{kg}$ treated group significantly decreased when compared to - alcohol only treated group (Table 1). This result showed that the elimination of alcohol in -rat treated with PSPE $300 \mathrm{mg} / \mathrm{kg}$ and HDE $300 \mathrm{mg} / \mathrm{kg}$ was faster than - alcohol only treated group. 
Table 2. Blood alcohol concentration in rat serum after alcohol administration

\begin{tabular}{lccc}
\hline \multirow{2}{*}{ Group } & \multicolumn{3}{c}{ Blood alcohol concentration (nmol/mM) } \\
\cline { 2 - 4 } & $\mathbf{0}$ in & $\mathbf{3 0}$ in & $\mathbf{1 2 0}$ min \\
\hline Alcohol & $2.19 \pm 0.03$ & $11.06 \pm 0.13$ & $2.26 \pm 0.52$ \\
Alcohol + PSPE $100 \mathrm{mg} / \mathrm{kg}$ & $1.98 \pm 0.03$ & $7.26 \pm 0.33^{*}$ & $6.90 \pm 0.46$ \\
Alcohol + PSPE $200 \mathrm{mg} / \mathrm{kg}$ & $2.00 \pm 0.17$ & $6.96 \pm 0.73^{*}$ & $5.32 \pm 0.71$ \\
Alcohol + PSPE $300 \mathrm{mg} / \mathrm{kg}$ & $1.99 \pm 0.17$ & $5.38 \pm 1.62^{* *}$ & $2.86 \pm 0.46^{*}$ \\
Alcohol + HDE $200 \mathrm{mg} / \mathrm{kg}$ & $2.23 \pm 0.48$ & $4.6 \pm 0.55^{* *}$ & $2.84 \pm 0.76^{*}$ \\
\hline
\end{tabular}

Data are presented as mean \pm SEM $(\mathrm{n}=3)$ for three independent experiments. ${ }^{*} P<0.05$ and ${ }^{* *} p<0.01$, compared with alcohol group

\section{Effect of PSPE on body weight, feed intake,} and water intake

Body weight, feed intake, and water intake were compared in Figure -1 . The body weight gains during 7 days of experimental periods were decreased significantly $(p<0.05)$ in alcohol group when compared with intact normal group. But increases of body weights were observed in 7th treatment day of test material in PSPE and HDE treated mice when compared with - alcohol group (Figure $1 \mathrm{~A}$ ). Daily feed intake and water intake was decreased significantly $(p<0.05)$ in alcohol group when compared with intact normal group. An enhanced feed intake and water intake were observed in test material in PSPE and HDE treated mice when compared with alcohol group, respectively (Figure $1 \mathrm{~B}$ and C).
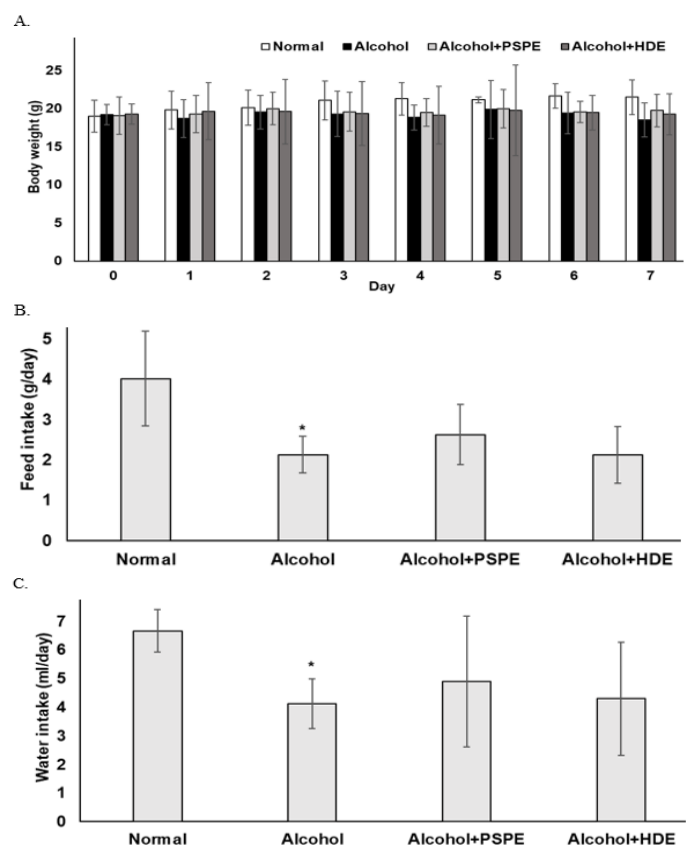

Figure 1: Effect of PSPE on body weight changes (A), feed intake (B), and water intake (C) in alcohol-fed mice. Data are showed as mean \pm SEM for three independent experiments; ${ }^{*} p<0.05$, compared with normal group by Student t-test

\section{Effects of PSPE on serum ALT and AST activity}

Alanine aminotransferase (ALT) activity in the alcohol treated group was significantly increased by alcohol administration compared to the untreated group However, PSPE and HDE diet group exhibited the significantly decreased the ALT activities (Figure 2A). The AST activity was alike to the ALT activity. However, there were no significant differences between the experimental groups (Figure 2B).
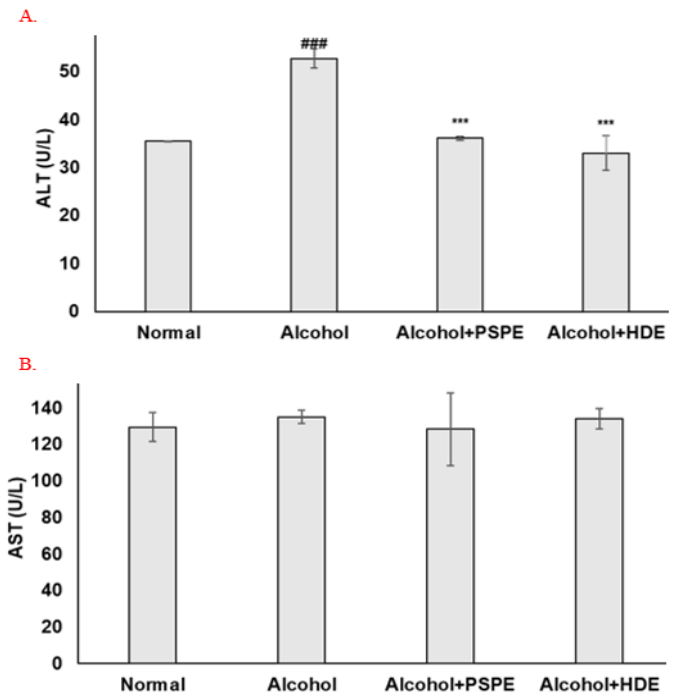

Figure 2: Effects of PSPE on serum ALT (A) and AST (B) activities in alcohol-fed mice. Data are showed as mean \pm SEM for three independent experiments; ${ }^{\#} p<$ 0.001 , when compared to normal group; ${ }^{* * *} p<0.001$ when compared to alcohol group by Student t-test

\section{Effect of PSPE on serum lipid profile}

Figure 3 shows changes in serum total cholesterol (TC) and triglycerides (TG) in the different experimental groups. The alcohol treated group significantly increased in the levels of serum TC and TG $\left({ }^{\#} P<0.001\right)$ in compared to normal group. Whereas, PSPE and HDE groups, serum TG and TC levels decreased (** $P<0.01)$ significantly compared to alcohol group. 


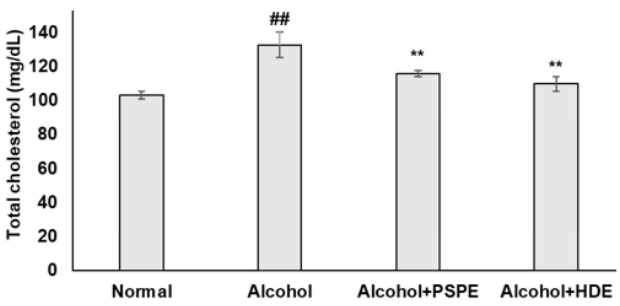

B.

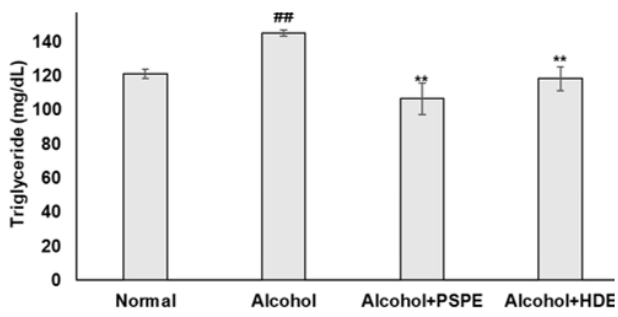

Figure 3: Effect of PSPE on serum total cholesterol (A) and triglyceride (B) in alcohol-fed mice. Data are showed as mean \pm SEM for three independent experiments; \#\# $p<0.01$; compared to control group. ${ }^{* *} p<0.01$; compared to ethanol group

\section{Effect of PSPE on histological changes in the liver}

To determine whether liver protection effect of PSPE in alcohol-fed mice, liver sections were stained with hematoxylin and eosin. Our results showed that inflammatory cells were increased in the alcohol group compared to the normal group, but spontaneously decreased in the PSPE or HDE-treated group.

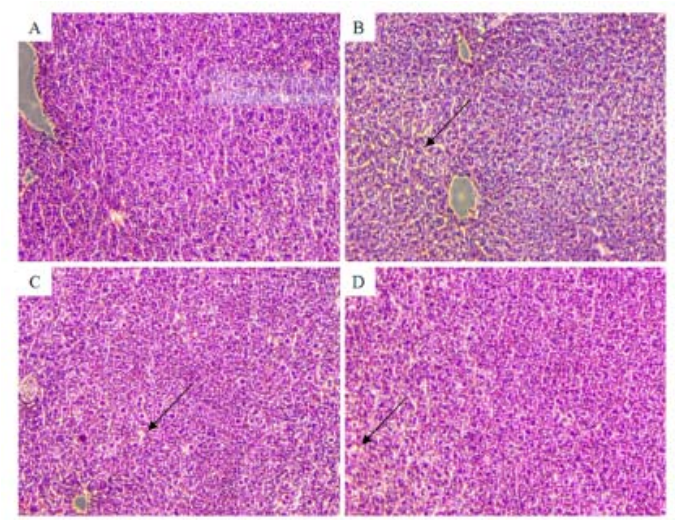

Figure 4: Effect of PSPE on morphology $H$ \& $E$ in alcohol-fed mice (200X). (A) Normal, (B) Alcohol, (C) Alcohol + PSPE, (D) Alcohol + HDE

\section{Effect of PSPE on hepatic alcohol metabolizing enzyme activities}

Figure 5 shows the results of measuring alcohol dehydrogenase $(A D H)$ enzyme activity in liver tissue to investigate the effect of PSPE on alcohol metabolism enzymes activity. The ADH activity in the normal group was $2.90 \pm 0.91 \mathrm{U} / \mathrm{g}$ protein, and the alcohol group showed statistically low activity as $1.34 \pm 0.39 \mathrm{U} / \mathrm{g}$ protein. The PSPE and HDE group showed statistically higher ADH activity than the alcohol group, with $1.88 \pm 0.23 \mathrm{U} / \mathrm{g}$ protein and $2.12 \pm 0.20 \mathrm{U} / g$ protein, respectively.

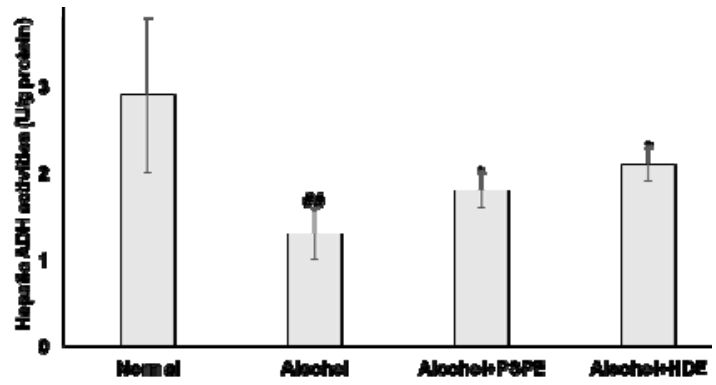

Figure 5: Effects of PSPE on hepatic alcohol metabolizing enzyme activites in alcohol-fed mice Data are presented as mean \pm SEM $(n=3)$ for three independent experiments; ${ }^{\#} p<0.01$; when compared to normal group; ${ }^{*} p<0.05$, compared to alcohol group

\section{Contents of chlorogenic acid in PSPE}

The analytical High-Performance Liquid Chromatography (HPLC) chromatograms of PSPE containing chlorogenic acid were presented in figure 6 . The calibration curves for the chlorogenic acid standards have been established. Content of chlorogenic acid in the PSPE was $5.16 \pm 0.05 \mu \mathrm{g} / \mathrm{mg}$.
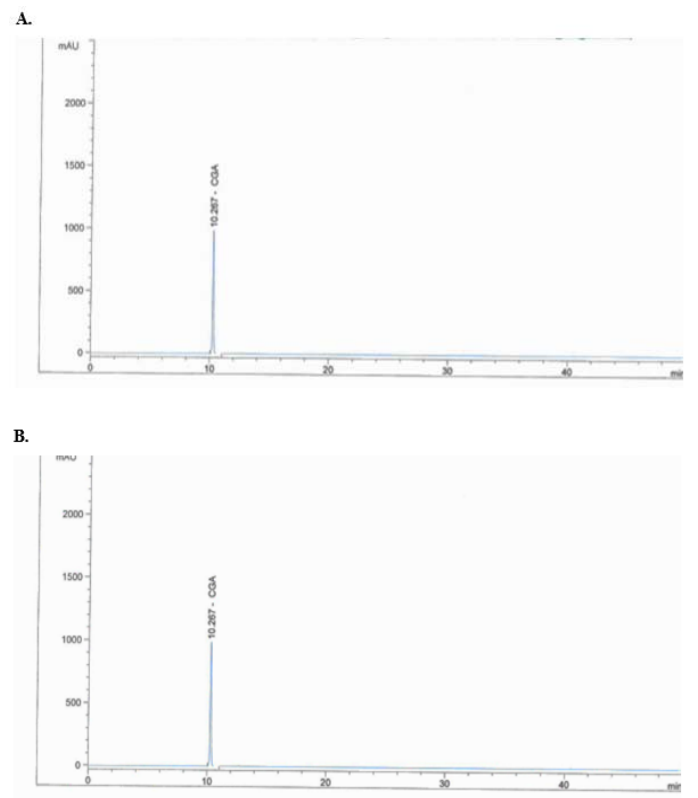

Figure 6: HPLC chromatograms of chlorogenic acid standard (A), PSPE (B)

Trop J Pharm Res, February 2021; 20(2): 305 


\section{DISCUSSION}

Ipomoea batatas Linn. from the family Convolvulaceae is a herbaceous perennial vine that has white and purple flowers, large nutritious storage roots and heart-shaped, lobed leaves [10]. It is consumed as vegetable in tropical areas, especially Southeast Asia, used as a folk medicine in Brazil and commonly eaten as root crop in Japan, Korea and other Asian countries $[10,11]$. Nutritionists at the Center for Science in the Public Interest (CSPI) reported that $I$. batatas is the single most important dietary crops that would replace fatty foods [12].

Traditionally, the leaves and roots of $I$. batatas have been used in treating urinary infections, reducing fever, skin diseases, diabetes, curing boils and acnes [13]. A review of pharmacological studies on $I$. batatas indicated that it possesses anti-diabetic, hypoglycemic, neuroprotective, antiproliferative, antioxidant, antiulcer, antitumor, anti-inflammatory, wound healing, antimutagenic and hepatoprotective properties [14]. Previous study reported that IBE extract significantly inhibited production of $\mathrm{NO}$, suppressed the expression of iNOS and COX-2 protein levels and attenuated increased TNF- $\alpha$ production in LPS-simulated BV-2 microglial cells. The IBE extract also exhibited significant antioxidant activity as evaluated by DPPH free radical scavenging assay [15].

Reports also reveal that $I$. batatas possess strong antioxidant compounds $[16,17]$. In the present study, the IBE extract also exhibited significant free radical-scavenging effect indicating that IBE extract might contain potential antioxidant agents. Previous studies on 3T3-L1 adipocytes in vitro revealed that $l$. batatas extract suppressed the inflammatory response [18]. The antioxidant glycosides and anthocyanin present in $I$. batatas have also been reported to exhibit anti-inflammatory effects $[19,20]$.

In the PSPE group, the serum level of AST and ALT were significantly attenuated compared to the HDE treatment group, suggesting that $I$. batatas has potential for use as HDE intervention. Choi et al [10] reported that $H$. dulcis decreased about $20 \%$ of blood alcohol concentration at $3 \mathrm{~h}$. In this study, after $30 \mathrm{~min}$, $300 \mathrm{mg} / \mathrm{kg}$ of PSPE group decreased the blood alcohol concentration as much as HDE 300 $\mathrm{mg} / \mathrm{kg}$ group.

Serum ALT and AST activities are reliable markers of liver function [21]. It is established that AST is present in liver, lung, kidney, skeletal muscle, pancreas, brain, cardiac muscle, erythrocytes, and leukocytes, whereas ALT is present in liver [22]. The increased levels of serum enzymes such as AST and ALT indicate increased permeability and injury and/or necrosis of hepatocytes [23]. In the current study, the levels of serum ALT and AST, as biomarkers of liver function, were significantly decreased in the group treated with PSPE-alone. Alanine aminotransferase and aspartate aminotransferase are simple and widely accepted biomarkers for hepatic dysfunction, indicating that the APAP-induced liver injury model has been successfully developed in mice [24].

In the early stage of alcohol liver disease, triglycerides accumulate in hepatocytes, resulting in a reversible condition fatty liver (steatosis). Alcoholic fatty liver (AFL) is one of the earliest and most common consequences of chronic and excess alcohol consumption and can lead to more serious forms of liver damage such as cirrhosis, steatohepatitis, and hepatic fibrosis in humans [25].

Levels of serum triglyceride and cholesterol increased from alcohol absorption. It might be due to several processes, such as increased availability of L-glycerophosphate and free fatty acids, decreased secretion of very low density [26]. These results showed that alcohol treatment group significantly elevated serum triglyceride level compared to alcohol untreated group. While PSPE-alone group significantly decreased serum TG level, suggesting that PSPE prevent hyperlipidemia. In addition, total cholesterol in serum also slightly decreased in PSPE-alone and HDE group.

Chlorogenic acid is a kind of phenolic compound that exists in most plants and is known as a compound that has strong antioxidant activity [27], and Shi et al [28] found that chlorogenic acid reduces inflammation caused by liver toxicity It has been reported to improve fibrosis. In addition, it has been reported that chlorogenic acid inhibits the biosynthesis of fatty acids and cholesterol by participating in the process of fat metabolism [29]. In this study, chlorogenic acid content of PSPE confirmed that it contained a content of $5.16 \pm 0.05 \mu \mathrm{g} / \mathrm{mg}$. Based on the above results, it is considered that the protective effect of PSPE against alcoholic liver damage is due to phenolic compounds such as chlorogenic acid derived from PSPE.

\section{CONCLUSION}

Alcohol administration significantly decreases liver and body weight. And PSPE administration 
significantly inhibits the increase in serum ALT and AST levels caused by alcohol. These results demonstrate that PSPE and HDE experimental group is a promising agent to protect the liver from hepatotoxicity and fatty liver induced by alcohol intake.

\section{DECLARATIONS}

\section{Acknowledgement}

This study was supported by Research Fund of Dankook University in 2020.

\section{Conflict of interest}

No conflict of interest is associated with this work.

\section{Contribution of authors}

We declare that this work was done by the authors named in this article and all liabilities pertaining to claims relating to the content of this article will be borne by the authors.

\section{Open Access}

This is an Open Access article that uses a funding model which does not charge readers or their institutions for access and distributed under the terms of the Creative Commons Attribution License (http://creativecommons.org/licenses/by/ 4.0) and the Budapest Open Access Initiative (http://www.budapestopenaccessinitiative.org/rea d), which permit unrestricted use, distribution, and reproduction in any medium, provided the original work is properly credited.

\section{REFERENCES}

1. Ramaiah SK, Rivera C, Arteel GE. Early-phase alcoholic liver disease: An update on animal models, pathology, and pathogenesis. Int J Toxicol 2004; 23: 217-231.

2. Gao B, Bataller R. Alcoholic liver disease: Pathogenesis and new therapeutic targets. Gastroenterol 2011; 141: 1572-1585.

3. Salaspuro MP, Shaw S, Jayatilleke E, Ross WA, Lieber CS. Attenuation of the ethanol-induced hepatic redox change after chronic alcohol consumption in baboons: metabolic consequences in vivo and in vitro. Hepatol 1981; 1: 33-38.

4. Zakhari S. Overview: how is alcohol metabolized by the body. Alcohol Res Health 2006; 29: 245-254.

5. Ding RB, Tian $K$, Huang $L L$, He CW, Jiang $Y$, Wang $Y T$, Wan JB. Herbal medicines for the prevention of alcoholic liver disease a review. J Ethnopharmacol 2012; 144: 457-465.
6. Wang S, Nie S, Zhu F. Chemical constituents and health effects of sweet potato. Food Res Int 2016; 89: 90-116.

7. Mohanraj R, Sivasankar S. Sweet potato (Ipomoea batatas (L.) Lam) - a valuable medicinal food: a review. J Med Food 2014; 17: 733-741.

8. Dini I, Tenore GC, Dini A. New polyphenol derivative in Ipomoea batatas tubers and its antioxidant activity. $J$ Agric Food Chem 2006; 54: 8733-8737.

9. Basnet $P$, Matsushige $K$, Hase K, Kadota S, Namba T. Four di-O-caffeoyl quinic acid derivatives from propolis potent hepatoprotective activity in experimental liver injury models. Biol Pharm Bull 1996; 19: 1479-1484.

10. Villareal RL, Tsou SC, Lo HF, Chiu SC. Sweet potato tips as vegetables. Sweet Potato: Proceedings of the First International Symposium. In: Villareal RL, Griggs TD, eds. AVRDC: Shanhua, Taiwan 1982; pp 313-320.

11. Sun $H, M u T, X i L$, Zhang $M$, Chen J. Sweet potato (Ipomoea batatas L.) leaves as nutritional and functional foods. Food Chem 2014; 156: 380-389.

12. Alternative home remedies. Health benefits of sweet potato [database on the internet]. Available from: http://www.foodreference.com/html/sweetpotnutrition.html

13. Stuartxchange [Internet]. Philippine. Philippine Medicinal Plants (PH); [updated 2012 July]. Available from: http://www.stuartxchange.org/Kamote.html.

14. Panda $V$ and Sonkamble M. Phytochemical and pharmacological activities of Ipomoeae batatas $L$. (Lam)-A review. Int J Phytochem Pharmacol 2012; 2: 25-34.

15. Kang H, Kwak YG, Koppula S, Protective Effect of Purple Sweet Potato (Ipomoea batatas Linn, Convolvulaceae) on Neuroinflammatory Responses in Lipopolysaccharide-Stimulated Microglial Cells. Trop J Pharm Res 2014; 13: 1257-1263.

16. Islam S, Yoshimoto O, Yamakawa. Distribution and Physiological Function of Caffeoylquinic Acid Derivatives in Sweet potato Genotypes. J Food Sci 2003; 68: 111-116.

17. Jiao $Y$, Yang Z, Jiang $Y$, Zhai W. Study on Chemical Constituents and Antioxidant Activity of Anthocyanins from Purple Sweet Potato (Ipomoea batatas L.) Int $J$ Food Eng 2012; 2: 1556-3758.

18. Ju JH, Yoon HS, Park HJ, Kim MY, Shin HK, Park KY, Yang JO, Sohn MS, Do MS. Anti-obesity and antioxidative effects of Purple Sweet Potato extract in 3T3-L1 adipocytes in vitro. J Med Food 2011; 14:10971106.

19. Kazuko Y, Chiho Y, Hiroshi H, Masami T, Shigenobu A, Toshihiro $H$. Ipomotaosides $A-D$, resin glycosides from the aerial parts of Ipomoea batatas and their inhibitory activity against COX-1 and COX-2. J Nat Prod 2010; 73(11): 1763-1766

20. Kano M, Takayanagi T, Harada K, Makino K, Ishikawa F. Antioxidative activity of anthocyanins from purple sweet potato, Ipomoera batatas cultivar Ayamurasaki. Biosci Biotechnol Biochem 2005; 69: 979-988.

Trop J Pharm Res, February 2021; 20(2): 307 
21. Choi GH, Kim JG, Kwon ST. Protective effects of food including Hovenia dulcis on acute alcohol intoxication. J. Korean Soc. Food Sci Nutr 2011; 40: 1107-1112.

22. Gross A, Ong TR, Grant R, Hoffmann T, Gregory $D D$, Sreerama $L$. Human aldehyde dehydrogenasecatalyzed oxidation of ethylene glycol ether aldehydes. Chemico-biological interaction 2009; 178: 56-63

23. Rej R. Aspartate aminotransferase activity and isoenzyme proportions in human liver tissues. Clin Chem 1978; 24: 1971-1979.

24. Goldberg $D$, Watts $C$. Serum enzyme changes as evidence of liver reaction to oral alcohol. Gastroenterol 1965; 49: 256.

25. Zheng S, Xiaomei L, Christopher QR, Drew R, Min $Y$. Involvement of adiponectin-SIRT1-AMPK signaling in the protective action of rosiglitazone against alcoholic fatty liver in mice. Ameri $\mathrm{J}$ of Physio-Gastrointestinal and Liver Physiol 2010; 298: G364-G374.
26. Sugimoto $T$, Yamashita S, Ishigami M, Sakai N, Hirano $K$. Tahara M, Matsumoto K, Nakamura T, Matsuzawa Y. Decreased microsomal triglyceride transfer protein activity contributes to initiation of alcoholic liver steatosis in rats. $J$ Hepatol 2002;36: 157-162.

27. Olthof MR, Hollman PC, Katan MB. Chlorogenic acid and caffeic acid are absorbed in humans. J Nutr 2001; 131: 66-71.

28. Shi H, Dong L, Jiang J, Zhao J, Zhao G, Dang X, Lu X, Jia M. Chlorogenic acid reduces liver inflammation and fibrosis through inhibition of toll-like receptor 4 signaling pathway. Toxicology 2013; 303: 107-114.

29. Cho AS, Jeon SM, Kim MJ, Yeo J, Seo KI, Choi MS, Lee MK. Chlorogenic acid exhibits anti-obesity property and improves lipid metabolism in high-fat diet-induced-obese mice. Food Chem Toxicol 2010; 48: 937-943. 